\title{
Bazı Kıșlık Nohut (Cicer arietinum L.) Hatlarında Bazı Tarımsal Karakterlerin ve Karakterler Arası İlișkilerin Belirlenmesi
}

\author{
${ }^{*}$ Muammer TEKATLI, Cevdet KILINÇ, Mehmet Akif ÇINKIR \\ Doğu Akdeniz Geçit Kușağı Tarımsal Araștırma Enstitüsü Müdürlüğü, Kahramanmaraș \\ *Sorumlu yazar e-posta (Corresponding author; e-mail): muammertekatli@hotmail.com
}

\section{Öz}

Araștırma, 2012-2013 yıllarında Kahramanmaraș Doğu Akdeniz Geçit Kușağı Tarımsal Araștırma Enstitüsü Müdürlüğü deneme alanında iki yıl süreyle yürütülmüștür. Denemede 8 hat ve 2 tescilli kontrol çeșidi (İnci ve Menemen-92) kullanılmıș ve tesadüf blokları deneme deseninde dört tekrarlamalı olarak kurulmuștur. Bu çalıșmada verim, yüz tane ağırlığı, bitki boyu, ilk bakla yüksekliği, bitkide bakla sayısı, bitkide dal sayısı, çiçeklenme ve olgunlașma gün sayısı özellikleri analiz edilmiș ve aralarındaki ilișki ortaya konulmuștur. İki yıllık birleștirilmiș ortalamalara göre en yüksek tane verimi 270.7 kgda-1 ile KMN 05589 hattından, en yüksek tane iriliği ise $53.3 \mathrm{~g}$ ile KMN 05-428 hattından elde edilmiștir. En yüksek bitki boyu $71.0 \mathrm{~cm}$ ile KMN 05-41 hattından elde edilmiș, KMN 05-589 hattı ise $44.2 \mathrm{~cm}$ ile ilk bakla yüksekliği açısından ilk sırada yer almıștır. Bitkide bakla sayısı açısından 19.8 adet tane ile KMN 05-428 hattı ilk sırayı almıș, bitkide dal sayısı bütün hat ve çeșitlerde iki civarı bulunmuștur. En erken çiçeklenme 79 gün ile İnci çeșidinde, en erken olgunlașma ise 122 gün ile Menemen-92 ve İnci çeșidinde gerçekleșmiștir. İstatistiksel olarak yüz tane ağırlığı, bitki boyu, ilk bakla yüksekliği, bitkide bakla sayısı, çiçeklenme ve olgunlașma gün sayıları yönünden çeșit ve hatlar arasında önemli farklılıklar bulunmuștur. Verim yönünden çeșit x yıl interaksiyonu önemsiz çıkmıștır. Korelasyon analizi sonucuna göre ise; ilk bakla yüksekliği ile bitki boyu, çiçeklenme gün sayısı ile bitki boyu ve ilk bakla yüksekliği, olgunlașma gün sayısı ile bitki boyu ve ilk bakla yüksekliği, olgunlașma gün sayısı ile çiçeklenme gün sayısı arasında çok önemli ve pozitif ilișki saptanmıștır.

Anahtar Kelimeler: Nohut, korelasyon, verim, hat, çeșit, interaksiyon

\section{Determination of the Relationships Some of the Agricultural Characters Among Certain Characters and in Some Winter Chickpea (Cicer arietinum L.) Lines}

\section{Abstract}

The research was carried out in the experimental area of the Kahramanmaraș Eastern Mediterranean Transitional Zone Agricultural Research Institute in 2012-2013. Eight lines and 2 registered control varieties (Inci and Menemen-92) were used in the experiment and four replications were established at random blocks trial design. In this study, characteristics of yield, hundred grain weight, plant height, first pod height, number of pods per plant, number of twig per plant, number of flowering and ripening days were analysed and the relationships among them were determined. According to two years, combined average, the highest grain yield was obtained from KMN 05-589 with $270.7 \mathrm{~kg}$ da-1 and the highest grain yield from KMN 05-428 with $53.3 \mathrm{~g}$. The highest plant height was obtained from KMN 05-41 with $71.0 \mathrm{~cm}$ and the first od height from KMN 05-589 with $44.2 \mathrm{~cm}$. Regarding the number of beans in the plant, by 19.8 seeds line KMN 05-428 had the most seeds, two twigs were found in all lines. The earliest flowering occurred in the CV Inci with 79 days, and the earliest ripening occurred in Menemen-92 and Inci with 122 days. Statistically significant differences were found between varieties and lines in terms of weight, plant height, first pod height, number of pods per plant, number of flowering and ripening days. Yield variety $x$ year interactions was not found important. According to the result of correlation analysis; the mutual relationships of, plant height with first pod height, plant height and first pod height with number of flowering days, plant height and first pod height with number of ripening days, and number of flowering days with number of ripening days were determined very important and positive.

Keywords: Chickpea, correlation, yield, line, variety, interaction 


\section{Giriș}

Y emeklik tane baklagiller kuru tanelerinde içerdikleri yüksek oranda protein, vitamin ve mineral maddeler yönünden insan ve hayvan beslenmesinde; kazık köklü olmaları ve havanın serbest azotunu toprağa bağlama özellikleri nedeniyle ekim nöbetlerinde ve bitkisel üretimde ekonomik önemi oldukça fazladır. Yemeklik tane baklagiller içerisinde nohut, dünyada ekim alanı yönünden fasulyeden sonra ikinci, üretim yönünden ise üçüncü sırada yer almaktadır. Ülkemizde ise en fazla ekiliș ve üretime sahip olan baklagil bitkisi nohuttur (Ercan ve ark., 2005). Son yıllarda dünya baklagil üretimi, ülkelerin biyodizel için mısır ve diğer bazı bitkileri teșvik etmeleri nedeniyle düșmüștür. Türkiye'de tarla bitkileri üretimi yapılan toplam alanın \%74'ünü tahıllar olușturmakta, \%8.3 ile yemeklik tane baklagiller 2. sırada yer almaktadır (TÜiK 2009). Kurak ve yarı-kurak alanlarda yetiștirilen nohut, nadas alanlarının daraltılması açısından oldukça önemlidir. Dünyada nohut ekim ve üretiminde Türkiye, Hindistan ve Pakistan'dan sonra 3. sırada yer almaktadır. 2009 yılı verilerine göre ülkemizde 455.000 ha ekim alanında 562.000 ton nohut üretimi gerçekleștirilmiștir. Dünya nohut ihracatında Türkiye, Avustralya, Hindistan ve Meksika'dan sonra 4. sırada gelmektedir (FAO 2009). Türkiye gibi sıcak iklime sahip bölgelerde kabuli tipi iri taneli ve bej rengi nohutlar üretilmekte iken, yarı kurak tropik bölgelerde desi tipi küçük, köșeli, siyah, kahverengi, sarı ve yeșil renkli nohutlar yetiștirilmektedir (Muehlbauer and Singh, 1987).

Bu çalıșmada, bölge verim denemesindeki nohut hatlarının bazı tarımsal karakterleri ile karakterler arasındaki korelasyon incelenmiștir.

\section{Materyal ve Yöntem}

Deneme, 2012-2013 yıllarında Kahramanmaraș Doğu Akdeniz Geçit Kușağı Tarımsal Araștırma Enstitüsü deneme arazisinde yürütülmüștür. Denemede, kontrol olarak iki tescilli nohut çeșidi (İnci ve Menemen-92) ve ileri verim kademesinde olan sekiz hat (KMN 05-589, KMN 05-428, KMN 05-36, KMN 05-41, KMN 05-280, KMN 05-292, KMN 05-297, KMN 05-298) kullanılmıștır.

Denemeler her iki yılda da tesadüf blokları deneme deseninde dört tekerrürlü olarak kurulmuștur. Parseller dört sıralı, sıra arası 48 $\mathrm{cm}$ ve parsel uzunluğu $5 \mathrm{~m}$ olarak alınmıștır. Ekimle birlikte $3 \mathrm{~kg} \mathrm{da}^{-1}$ saf $\mathrm{N}$ ve $6 \mathrm{~kg} \mathrm{da}^{-1}$ saf $\mathrm{P}$ düșecek șekilde DAP gübresi atılmıștır. Yabancı ot kontrolü traktör çapası ve el çapası ile yapılmıștır. Ekimler kıșlık olarak Ocak ayında yapılmıș, Șubat ayı içerisinde çıkıșlar gerçekleșmiștir. Çıkıștan itibaren çiçeklenme gün sayısı, olgunlașma gün sayısı, bitki boyu, ilk bakla yüksekliği, bitkide dal sayısı, bitkide bakla sayısı, yüz tane ağırlığı ve verim gözlemleri alınmıștır. Alınan gözlem değerleri varyans analizine tabi tutulmuș ve istatistiksel

Çizelge 1. 2012-2013 Yılı Nohut Bölge Verim Denemeleri iki yıllık gözlem ortalamaları ve istatistiksel gruplandırmalar

Table 1. 2012-2013 Seasoned Chickpea Region Yield Experiments 2 year observation averages and statistical groupings

\begin{tabular}{|c|c|c|c|c|c|}
\hline Sıra No & Çeșit/Hat Adı & Verim $\left(\mathrm{kgda}^{-1}\right)$ & Yüz tane ağırlığı (gr) & Bitki boyu $(\mathrm{cm})$ & İlk bakla yüksekliği (cm) \\
\hline 1 & KMN 05-589 & 270.7 & $49.9 \mathrm{bcd}$ & $65.7 \mathrm{c}$ & $44.2 \mathrm{a}$ \\
\hline 2 & İnci & 263.9 & $38.4 \mathrm{f}$ & $53.0 \mathrm{~d}$ & $33.2 \mathrm{c}$ \\
\hline 3 & KMN 05-36 & 250.4 & $49.0 \mathrm{~d}$ & $68.8 \mathrm{ab}$ & $42.0 \mathrm{a}$ \\
\hline 4 & KMN 05-298 & 247.5 & $49.6 \mathrm{bcd}$ & $70.1 \mathrm{a}$ & $42.7 \mathrm{a}$ \\
\hline 5 & KMN 05-297 & 245.6 & $49.7 \mathrm{bcd}$ & $70.8 \mathrm{a}$ & $41.8 \mathrm{a}$ \\
\hline 6 & Menemen-92 & 241.1 & $43.5 \mathrm{e}$ & $55.0 \mathrm{~d}$ & $33.0 \mathrm{c}$ \\
\hline 7 & KMN 05-280 & 230.7 & $49.4 \mathrm{~cd}$ & $69.7 \mathrm{a}$ & $42.7 \mathrm{a}$ \\
\hline 8 & KMN 05-41 & 221.6 & $51.1 \mathrm{bc}$ & $71.0 \mathrm{a}$ & $42.6 \mathrm{a}$ \\
\hline 9 & KMN 05-428 & 215.0 & $53.3 \mathrm{a}$ & $65.8 \mathrm{bc}$ & $38.6 \mathrm{~b}$ \\
\hline 10 & KMN 05-292 & 210.7 & $51.2 \mathrm{~b}$ & $68.6 \mathrm{abc}$ & $43.6 \mathrm{a}$ \\
\hline \multicolumn{2}{|r|}{ F çeșit } & ö. d. & $\star \star$ & $\star \star$ & $\star \star$ \\
\hline \multicolumn{2}{|r|}{ F yılxçeșit } & ö. d. & ö. d. & ** & $\star \star *$ \\
\hline
\end{tabular}

*: \%5, ${ }^{* *}: \% 1$ istatistiksel olarak öneml

*: $5 \%, * *: 1 \%$ statistically significant 
Çizelge 2. 2012-2013 Yılı Nohut Bölge Verim Denemeleri iki yıllık gözlem ortalamaları ve istatistiksel gruplandırmalar

Table 1. Chickpea Regional Yield Experiments of two years observation averages and statistical groupings in 2012 and 2013

\begin{tabular}{|c|c|c|c|c|c|}
\hline Sıra No & Çeșit/Hat Adı & $\begin{array}{c}\text { Bitkide bakla } \\
\text { sayısı }\end{array}$ & $\begin{array}{c}\text { Bitkide dal } \\
\text { sayısı }\end{array}$ & $\begin{array}{c}\text { Çiçeklenme gün } \\
\text { sayısı }\end{array}$ & $\begin{array}{c}\text { Olgunlașma gün } \\
\text { sayısı }\end{array}$ \\
\hline 1 & KMN 05-589 & $11.5 \mathrm{e}$ & 2.1 & $87.3 \mathrm{ab}$ & $124.9 \mathrm{c}$ \\
\hline 2 & İnci & $12.2 \mathrm{de}$ & 2.0 & $79.0 \mathrm{e}$ & $122.0 \mathrm{~d}$ \\
\hline 3 & KMN 05-36 & $15.1 \mathrm{~b}-\mathrm{e}$ & 2.0 & $86.5 a b$ & $125.1 \mathrm{bc}$ \\
\hline 4 & KMN 05-298 & $17.6 \mathrm{abc}$ & 2.0 & $86.4 \mathrm{abc}$ & $125.5 \mathrm{abc}$ \\
\hline 5 & KMN 05-297 & $18.8 \mathrm{ab}$ & 2.1 & 85.5 bc & $125.6 \mathrm{abc}$ \\
\hline 6 & Menemen-92 & $15.1 \mathrm{~b}-\mathrm{e}$ & 2.2 & $81.1 \mathrm{~d}$ & $121.8 \mathrm{~d}$ \\
\hline 7 & KMN 05-280 & $15.7 \mathrm{a}-\mathrm{d}$ & 1.9 & $87.5 \mathrm{a}$ & $126.4 \mathrm{ab}$ \\
\hline 8 & KMN 05-41 & $17.4 \mathrm{abc}$ & 2.1 & $87.0 \mathrm{ab}$ & $125.1 \mathrm{bc}$ \\
\hline 9 & KMN 05-428 & $19.8 \mathrm{a}$ & 1.8 & $84.6 \mathrm{c}$ & $126.1 \mathrm{abc}$ \\
\hline 10 & KMN 05-292 & $14.5 \mathrm{cde}$ & 1.9 & $86.6 a b$ & $126.8 \mathrm{a}$ \\
\hline F çeșit & & ** & ö. d & ** & ** \\
\hline F yıl x çeșit & & ö. d. & ö. d. & $\star *$ & ö. d. \\
\hline
\end{tabular}

olarak önem derecesine göre gruplandırılmıștır. Korelasyon analizi ile karakterler arasındaki ilișki ortaya konulmuștur.

\section{Bulgular ve Tartıșma}

Çizelge 1'e göre verim bakımından çeşit ve çeşit x yıl interaksiyonları önemsiz bulunmuştur. En yüksek verimi $270.7 \mathrm{kgda}^{-1}$ ile KMN 05-589 hattı, en düșük verimi ise $210.7 \mathrm{kgda}^{-1}$ ile $\mathrm{KMN}$ 05-292 hattı vermiștir. Yüz tane ağırlığı olarak çeșitler arasındaki fark 0.01 düzeyinde önemli bulunmuș, çeșit x yıl interaksiyonu ise önemsiz çıkmıștır. Çeșit ve hatların yüz tane ağılı̆̆ı 53.3 $\mathrm{g}$ ile $43.5 \mathrm{~g}$ arasında değișmiștir. Bitki boyu ve ilk bakla yüksekliği yönünden çeșit ve çeșit x yıl interaksiyonları 0.01 düzeyinde önemli bulunmuștur. Çeșit ve hatların bitki boyları 71.0 $\mathrm{cm}$ ile $65.7 \mathrm{~cm}$ arasında; ilk bakla yükseklikleri ise $44.2 \mathrm{~cm}$ ile $33.0 \mathrm{~cm}$ arasında değișim göstermiștir. Bitki boyu, ilk bakla yüksekliği, bitkide bakla sayısı ve yüz tane ağırlığı ile ilgili bulgular Biçer ve Șakar (2003), Özçelik ve Bozoğlu (2004)'nun bulgularıly uyumluluk göstermektedir.

Çizelge 2'ye göre bitkide bakla sayısı bakımından çeşitler arasındaki fark 0.01 düzeyinde önemli bulunmuş, çeşit $x$ yıl interaksiyonu ise önemsiz çıkmıştır. Bitkide bakla sayısı 19.8 adet ile 11.5 adet arasında değişmiştir. Bitkide dal sayısı yönünden çeşit

Çizelge 3. İki yıllık ortalamalara göre karakterler arası korelasyon analizi değerleri

Table 3. Correlation analysis values between characters by two-year average

\begin{tabular}{|c|c|c|c|c|c|c|c|c|}
\hline & Verim & $\begin{array}{l}\text { Yüz tane } \\
\text { ağırlığı }\end{array}$ & $\begin{array}{l}\text { Bitki } \\
\text { boyu }\end{array}$ & $\begin{array}{c}\text { İlk bakla } \\
\text { yüksekliği }\end{array}$ & $\begin{array}{l}\text { Bitkide } \\
\text { bakla } \\
\text { sayısı }\end{array}$ & $\begin{array}{l}\text { Bitkide } \\
\text { dal } \\
\text { sayısı }\end{array}$ & $\begin{array}{c}\text { Çiçeklenme } \\
\text { gün } \\
\text { sayısı }\end{array}$ & $\begin{array}{l}\text { Olgunlașma } \\
\text { gün } \\
\text { sayısı }\end{array}$ \\
\hline Verim & 1 & -0.1096 & -0.1094 & 0.0161 & -0.2262 & 0.1465 & -0.0476 & -0.0143 \\
\hline $\begin{array}{l}\text { Yüz tane } \\
\text { ağırlığı }\end{array}$ & -0.1096 & 1 & 0.52 & 0.4997 & 0.2345 & -0.0903 & 0.1971 & 0.1526 \\
\hline Bitki boyu & -0.1094 & 0.52 & 1 & 0.9322 & 0.2318 & -0.123 & 0.8227 & 0.7716 \\
\hline $\begin{array}{l}\text { İlk bakla } \\
\text { yüsekliği. }\end{array}$ & 0.0161 & 0.4997 & 0.9322 & 1 & -0.005 & -0.139 & 0.7695 & 0.716 \\
\hline $\begin{array}{l}\text { Bitide. bakla } \\
\text { sayısı }\end{array}$ & -0.2262 & 0.2345 & 0.2318 & -0.005 & 1 & 0.2793 & 0.1251 & 0.1096 \\
\hline $\begin{array}{l}\text { Bitkide dal } \\
\text { sayısı }\end{array}$ & 0.1465 & -0.0903 & -0.123 & -0.139 & 0.2793 & 1 & -0.0562 & -0.0695 \\
\hline $\begin{array}{l}\text { Çiçeklenme } \\
\text { gün sayısı }\end{array}$ & -0.0476 & 0.1971 & 0.8227 & 0.7695 & 0.1251 & -0.0562 & 1 & 0.9913 \\
\hline $\begin{array}{l}\text { Olgunlașma } \\
\text { gün sayısı }\end{array}$ & -0.0143 & 0.1526 & 0.7716 & 0.716 & 0.1096 & -0.0695 & 0.9913 & 1 \\
\hline
\end{tabular}


ve çeşit $x$ yıl interaksiyonu önemsiz çıkmıştır. Bütün hat ve çeşitlerde bitkide dal sayısı iki civarı bulunmuștur. Çiçeklenme gün sayısı olarak çeșit ve çeșit x yıl interaksiyonları 0.01 düzeyinde önemli bulunmuștur. Çiçeklenme gün sayıları aynı zamanda bir erkencilik kriteridir. 79.0 gün ile İnci en erkenci çeșit olurken, 87.5 gün ile KMN 05-280 hattı en geççi çeșit olmuștur. Olgunlașma gün sayısı yönünden çeșitler arasındaki fark 0.01 düzeyinde önemli bulunmuș, çeșit x yıl interaksiyonu ise önemsiz bulunmuștur. Menemen-92 çeșidi 121.8 gün ile en erken hasada gelen çeșit olurken, KMN 05-292 hattı 126.8 gün ile en geç hasada gelen çeșit olmuștur.

Çizelge 3'teki korelasyon analizi sonucuna göre; ilk bakla yüksekliği ile bitki boyu, çiçeklenme gün sayısı ile bitki boyu ve ilk bakla yüksekliği, olgunlaşma gün sayısı ile bitki boyu ve ilk bakla yüksekliği, olgunlaşma gün sayısı ile çiçeklenme gün sayısı arasında çok önemli ve pozitif ilişki saptanmıştır. Bitki boyu ile ilk bakla yüksekliği arasındaki pozitif ilişki Tolukan ve Engin (1990), Açıkgöz ve Açıkgöz (1994)'ün bulgularıyla uyumluluk göstermektedir.

\section{Sonuç}

Verim ve tane iriliği bakımından standart çeșitlerden daha üstün performans gösteren KMN 05-589, KMN 05-36, KMN 05-297 ve KMN 05-298 nohut hatları yeni çeșit geliștirmede ümitvar olarak görülmüștür.

\section{Kaynaklar}

Açıkgöz N. ve Açıkgöz N., 1994. Nohutta farklı ekim zamanı ve çeșitlerde verimin olușmasında etkili olan özelliklerin Path analizi ile irdelenmesi. Tarla
Bitkileri Kongresi, 25-29 Nisan, Bornova, İzmir Açıkgöz N. ve Kıtıkı A., 1994. Nohutta F2 ve F3 generasyonlarında bazı özellikler arasındaki korelasyonun saptanması. Tarla Bitkileri Kongresi, 25-29 Nisan, Bornova, İzmir

Atmaca E., 2005. Eskișehir koșullarında bazı nohut çeșit ve hatlarında farklı ekim zamanı ve sıra arası mesafelerinin verim, verim unsurları ve kalite üzerine etkisi. Yüksek lisans tezi, Ankara Üniversitesi Fen Bilimleri Enstitüsü, s.99

Babagil G.E., 2010. Muș ekolojik koșullarında bazı nohut (Cicer arietinum L.) çeșitlerinin verim ve verim unsurlarının değerlendirilmesi. Tekirdağ Ziraat Fakültesi Dergisi, 7(3): 181-186

Biçer B.T. ve Șakar D., 2003. Bazı nohut hat ve çeșitlerinde tarımsal karakterlerin belirlenmesi ve karakterler arası ilișkiler. Türkiye V. Tarla Bitkileri Kongresi, 13-17 Ekim, Diyarbakır, Cilt I: 499-503

Biçer B.T. ve Șakar D., 2003. F3 - F4 nohut genotiplerinde bazı tarımsal karakterlerin belirlenmesi. Türkiye V. Tarla Bitkileri Kongresi, 13-17 Ekim, Diyarbakır, Cilt I: 516-518

Encan G., Kaya M. ve Çiftçi C.Y., 2005. Nohutun Dünya ve Türkiye ekonomisindeki yeri. Süleyman Demirel Üniversitesi Fen Bilimleri Enstitüsü Dergisi, 9(1): 19-29

FAO 2009. Faostat, Agriculture. http://www.fao. org/faostat

Muehlbauer F.J. and Singh K.B., 1987. Genetics of Chickpea. In: Saxena, M.C., Singh, K.B., (Eds.), The Chickpea, CAB. International, Wallingford, Oxon, Ox 108 DE, U.K., pp. 99-125

Özçelik H. ve Bozoğlu H., 2004. Nohut (Cicer arietinum L.) çeșitlerinin tane verimi ve bazı özellikler arasındaki ilișkiler ve kalıtım derecesinin belirlenmesi üzerine bir araștırma. Ondokuz Mayıs Üniversitesi Ziraat Fakültesi Dergisi, 19(3): 8-13

Tolukan M. ve Engin M., 1990. Çukurova șartlarında uygun nohut (Cicer arietinum L.) çeșitlerinin belirlenmesi üzerine bir araștırma. Yüksek lisans tezi, Ç.Ü. Fen Bilimleri Enstitüsü

TÜiK 2009. Bitkisel Üretim İstatistikleri. T.C. Bașbakanlık Türkiye İstatistik Kurumu. http:// www.tuik.gov.tr 